\title{
US agencies 'agree earmarks by telephone'
}

Washington. A committee of the US House of Representatives is due to hear accusations this week that some federal agencies are so eager to please their congressional paymasters that they accept instructions over the telephone to 'earmark' science money for pet projects in their constituencies.

But at least one university president John Silber of Boston University - is expected to support earmarking as a way of funding new laboratories. Without it, he says, the United States would never have constructed a whole stream of worldfamous facilities, including Fermilab, the nuclear weapons laboratories and the Jet Propulsion Laboratory in California.

Furthermore, with both congressmen and senators preparing for November's mid-term elections, the debate takes place at a time when earmarking seems about to rebound from last year's dip. The election is likely to be accompanied by much talk of the need for fiscal responsibility. But a possible power switch from Democrats to Republicans in the Senate - and perhaps even the Housewould mean new committee chairmen, and thus a new set of universities well placed geographically to benefit from political largesse.

In the US system, budgets and priorities are prepared by federal agencies in cooperation with the administration. They are then sent to Congress for approval. Those who do this have always 'earmarked' a few dollars for their pet projects. But, over the past ten years, the scale of the practice has grown drastically, leading critics such as George Brown (Democrat, California), chairman of the House Science, Space and Technology Committee, to allege that it is undermining the process by which agencies are supposed to allocate funds on the basis of merit.

At a series of hearings this week, Brown will question officials of the Environmental Protection Agency (EPA) about telephone calls it is said to have received from congressional committee staff members. He is planning to use the hearings to press the Clinton administration to issue an executive order reminding agencies that they are not obliged to fund projects that appropriation committees ask for in the report language attached to budget bills.

Brown will also question the presidents of several universities which have lobbied Congress successfully for earmarked funds. At least one - Silber - will offer a vigorous defence of earmarking as helping science departments in small institutions to compete with the handful of leading universities that win the bulk of federal funding for peer-reviewed science.

Universities large and small have privately expressed misgivings about the timing of the Brown hearings, which coincide with the conference between the House and
Senate to finalize the defence budget bill. The House side, led by John Murtha (Democrat, Pennsylvania), has proposed cutting by half the $\$ 1.8$ billion spent by the Department of Defense on university research. But university officials say the final budget figures were expected to be agreed before the hearings, with university research cut by about $\$ 180$ million.

The hearings take place soon after another budget bill with a strong science con-

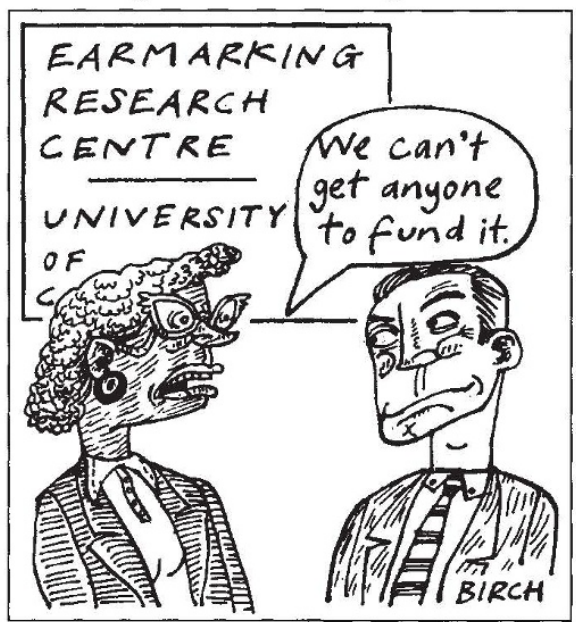

tent, covering agencies such as the National Science Foundation and the National Aeronautics and Space Administration, was passed by Congress with an unexpectedly large number of earmarks attached, with a total value of $\$ 290$ million. This includes $\$ 70$ million for universities, compared to $\$ 8$ million last year. A move by Brown on the floor of the House to eliminate these earmarks failed last week by nine votes.

At this week's hearing, Martha Krebs, director of research at the Department of Energy (DoE), was expected to defend her department's decision to divert funds away from the administration's stated research priorities - specifically, the Human Genome Project - to pay for earmarked

projects apparently unrelated to the department's missions.

The committee was also planning to question M. R. C. Greenwood of the White House Office of Science and Technology Policy about how far the administration is prepared to resist pressure from Congress to quietly fund earmarks. Greenwood is likely to restate the administration's opposition to earmarking, but her testimony will fall short of promising the executive order which Brown seeks.

It will then move to the Department of Defense (DoD). John Deutch, the deputy defence secretary - a firm opponent of earmarking - is likely to confirm the corrosive effects of the practice. But congressmen will want to know why so little has been done at the Pentagon to discourage it since Deutch's arrival last year.

Silber is set to clash directly with Brown when he gives evidence defending the recent earmarking of $\$ 28$ million of DoD money to build a photonics research centre at Boston University. Silber describes as "sheer hypocrisy" the way in which leading research universities have sided with Brown when they "all have had earmarked funds in the past".

According to Silber, Boston University has established highly successful departments - including the sixth best physics department in the United States, in terms of papers cited - through obtaining earmarked funds to build facilities. "The Congress has got a hell of a bang for their buck" through these earmarks, he says.

Silber does not deny using lobbyists to win earmarks, although he vehemently denies that earmarking is biased by the allocation of seats on congressional appropriations committees. He concedes that the Boston photonics centre, which will explore the science of optical signals, was not in the DoD budget request. "But it was a DoD priority, and the DoD was very pleased to have it," he says.

Colin Macilwain

\section{UN meeting backs contraceptive research}

London. Attempts by the Vatican to dilute key phrases in the programme of action agreed at the United Nations conference on population, which ended in Cairo last week, failed to alter significantly the thrust of the 20-year plan.

The Vatican's action meant that delegates at the main session spent much of the ten-day conference discussing references to abortion. But relatively few changes were made to the wording of the final document - including sections asking for more funds to be spent on contraceptive research (see Nature 370, 498; 1994).

No figure was specified by the meeting.
But the need for new male methods and female barrier methods that protect against sexually transmitted disease was emphasized to the conference by Prakash Tandon, former president of the Indian National Science Academy.

Tandon was representing the Inter-Academies Panel on Population Development set up last year by most of the world's science academies. "Scientists are increasingly concerned with the decreasing [support for] research and development in the general field of population dynamics, and specifically in the field of contraceptive research," says Tandon.

Maggie Verrall 